\title{
ОБЯЗАТЕЛЬНЫЕ РАБОТЫ КАК НОВЫЙ ВИД АДМИНИСТРАТИВНОГО НАКАЗАНИЯ
}

$\mathrm{O}$ дним из наиболее распространенных и востребованных на современном этапе видов юридической ответственности является административная ответственность. Этот институт, начавший формироваться со второй половины XIX в., после принятия в 1864 г. Устава о наказаниях, сегодня активно участвует в обеспечении стабильности общественной жизни и повышении гарантий защищенности прав граждан, тем самым приобретая значимость эффрективного правового способа воздействия на общественные отношения ${ }^{1}$. Административная ответственность базируется на принципах, заложенных в Конституции РФ и регламентируется федеральным законодательством и законодательством субъектов фредерации.

В качестве важнейшего инструментария административной ответственности выступает административное наказание - установленная государством мера ответственности за совершение административного правонарушения, применяемая в целях предупреждения совершения новых правонарушений как самим правонарушителем, так и другими лицами. Кодексом РФ об административных правонарушениях (КоАП РФ) устанавливается исчерпывающий перечень административных наказаний, которые могут предусматриваться в качестве санкций за совершение административных правонарушений. Вместе с тем, указанный перечень не постоянен: в целях адекватного реагирования на общественные процессы, обеспечения соответствия административного законодательства существующим общественным отношениям законодатель может исключать некоторые виды административных наказаний (в пример можно привести исключение возмездного изъятия орудия совершения или предмета адми-

\footnotetext{
${ }^{1}$ См.: Серков П.П. Административная ответственность в российском праве: современное осмысление и новые подходы. - М., 2012. - С. 8.
}

нистративного правонарушения из перечня видов административных наказаний ${ }^{2}$ или, напротив, вводить новые виды административных наказаний.

Летом 2012 г. был принят Федеральный закон «О внесении изменений в Кодекс РФ об административных правонарушениях и Федеральный закон «О собраниях, митингах, демонстрациях, шествиях и пикетированиях ${ }^{3}$, согласно положениям которого в КоАП РФ появился новый вид административного наказания - обязательные работы. Для российского административно-деликтного законодательства введение подобного вида наказания является новеллой, так как до этого КоАП РФ не предусматривал подобных санкций. Правда, ранее Кодекс РСФСР об административных правонарушениях от 20 июня 1984 г. (в настоящее время утратил силу) устанавливал в качестве меры административного взыскания исправительные работы, применявшиеся на срок от пятнадцати дней до двух месяцев с отбыванием их по месту постоянной работы лица, совершившего административное правонарушение, и с удержанием до двадцати процентов его заработка в доход государства, однако КоАП РФ не воспринял данный вид наказания.

В 2004 г. были введены в действие положения Уголовного кодекса РФ (УК РФ) о наказании в виде обязательных работ. Согласно ст. 49 УК РФ, обязательные работы заключаются в выполнении осужденным в свободное от основной работы или учебы время бесплатных общественно

\footnotetext{
${ }^{2}$ См.: Федеральный закон от 28 декабря 2010 г. № 398-Ф3 «О внесении изменений в отдельные законодательные акты РФ по вопросу усиления контроля в сфере оборота гражданского оружия» // СЗ РФ. - 2011. - № 1. - Ст. 10.

3 Федеральный закон от 8 июня 2012 г. № 65-Ф3 «О внесении изменений в Кодекс РФ об административных правонарушениях и Федеральный закон «О собраниях, митингах, демонстрациях, шествиях и пикетированиях» // СЗ РФ. - 2012. № 24 . - Ст. 3082.
} 
полезных работ. Вид обязательных работ и объекты, на которых они отбываются, определяются органами местного самоуправления по согласованию с уголовно-исполнительными инспекциями. Обязательные работы устанавливаются на срок от шестидесяти до четырехсот восьмидесяти часов и отбываются не свыше четырех часов в день.

Федеральный закон «О внесении изменений в Кодекс РФ об административных правонарушениях и Федеральный закон «О собраниях, митингах, демонстрациях, шествиях и пикетированиях» устанавливает обязательные работы уже в качестве вида административного наказания. Обязательные работы могут устанавливаться и применяться только в качестве основного административного наказания. Они назначаются судьей и заключаются в выполнении фризическим лицом, совершившим административное правонарушение, в свободное от основной работы, службы или учебы время бесплатных общественно полезных работ. Обязательные работы устанавливаются на срок от двадцати до двухсот часов и отбываются не более четырех часов в день. В то же время, обязательные работы не применяются к беременным женщинам, женщинам, имеющим детей в возрасте до трех лет, инвалидам I и II групп, военнослужащим, гражданам, призванным на военные сборы, а также к имеющим специальные звания сотрудникам органов внутренних дел, органов и учреждений уголовно-исполнительной системы, Государственной противопожарной службы, органов по контролю за оборотом наркотических средств и психотропных веществ и таможенных органов ${ }^{4}$.

В настоящее время обязательные работы уже установлены в качестве санкций за ряд административных правонарушений, в том числе за нарушение установленного порядка организации либо проведения собрания, митинга, демонстрации, шествия или пикетирования (ст. 20.2 КоАП РФ); организацию массового одновременного пребывания и (или) передвижения граждан в общественных местах, повлекших нарушение общественного порядка (ст. 20.2.2 КоАП РФ); блокирование транспортных коммуникаций (ст. 20.18 КоАП РФ).

Согласно ст. 32.13 КоАП РФ, постановление судьи о назначении обязательных работ исполняется судебным приставом-исполнителем в по-

\footnotetext{
4 См.: ст. 3.13 КоАП РФ.
}

рядке, установленном федеральным законодательством ${ }^{5}$. Виды обязательных работ и перечень организаций, в которых лица, которым назначено административное наказание в виде обязательных работ, отбывают обязательные работы, определяются органами местного самоуправления по согласованию с территориальными органами Федеральной службы судебных приставов. Виды обязательных работ, для выполнения которых требуются специальные навыки или познания, не могут определяться в отношении лиц, не обладающих такими навыками или познаниями.

Лицо, которому назначено соответствующее административное наказание, привлекается к отбыванию обязательных работ не позднее десяти дней со дня возбуждения судебным приставом-исполнителем исполнительного производства. Судебные приставы-исполнители ведут учет лиц, которым назначено административное наказание в виде обязательных работ, разъясняют таким лицам порядок и условия отбывания обязательных работ, согласовывают с органами местного самоуправления перечень организаций, в которых лица, которым назначено указанное административное наказание, отбывают обязательные работы, контролируют поведение таких лиц, ведут суммарный учет отработанного ими времени. В свою очередь лица, которым назначено указанное административное наказание, обязаны соблюдать правила внутреннего распорядка организаций, в которых они отбывают обязательные работы, добросовестно работать на определяемых для них объектах в течение установленного судом срока обязательных работ, ставить в известность судебного пристава-исполнителя об изменении места жительства, а также являться по его вызову.

Предоставление лицу, которому назначено административное наказание в виде обязательных работ, ежегодного оплачиваемого отпуска по основному месту работы не приостанавливает исполнение соответствующего административного наказания. Лицо, которому назначено административное наказание в виде обязательных работ, вправе обратиться в суд с ходатайством об освобождении от дальнейшего отбывания обязательных работ в случае признания его инвалидом I или II группы, наступления беременности либо

\footnotetext{
${ }^{5}$ См.: Федеральный закон от 2 октября 2007 г. № 229-Ф3 «Об исполнительном производстве» // СЗ РФ. - 2007. № 41. - Ст. 4849.
} 
тяжелой болезни, препятствующей отбыванию обязательных работ. Об удовлетворении данного ходатайства судья выносит постановление о прекращении исполнения постановления о назначении административного наказания в виде обязательных работ.

Обязательные работы выполняются на безвозмездной основе. Срок обязательных работ исчисляется в часах, в течение которых лицо отбывало обязательные работы. При этом время обязательных работ не может превышать четырех часов в выходные дни и в дни, когда лицо не занято на основной работе, службе или учебе; в рабочие дни - двух часов после окончания работы, службы или учебы, а с согласия лица, подвергнутого обязательным работам, - четырех часов. Время обязательных работ в течение недели, как правило, не может быть менее двенадцати часов. При наличии уважительных причин судебный пристав-исполнитель вправе разрешить лицу, которому назначено административное наказание в виде обязательных работ, отработать в течение недели меньшее количество часов.

На администрацию организации, в которой лицо отбывает обязательные работы, возлагаются контроль за выполнением этим лицом определенных для него работ, уведомление судебного пристава-исполнителя о количестве отработанных часов или об уклонении этого лица от отбывания обязательных работ. В случае уклонения лица от отбывания обязательных работ, выразившегося в неоднократном отказе от выполнения работ, и (или) неоднократном невыходе такого лица на обязательные работы без уважительных причин, и (или) неоднократном нарушении трудовой дисциплины, подтвержденных документами организации, в которой лицо отбывает обязательные работы, судебный пристав-исполнитель составляет протокол об административном правонарушении, предусмотренном ч. 4 ст. 20.25 КоАП Р $\Phi^{6}$.

Как известно, нормы Федерального закона от 8 июня 2012 г. № 65-Ф3 вызвали широкий общественный резонанс еще на стадии предварительного обсуждения, когда соответствующий законопроект был внесен на рассмотрение Государственной Думы Федерального Собрания РФ.

\footnotetext{
6 Часть 4 ст. 20.25 КоАП РФ предусматривает санкцию в виде административного штрафа в размере от ста пятидесяти тысяч до трехсот тысяч рублей или в виде административного ареста на срок до пятнадцати суток за уклонение от отбывания обязательных работ.
}

Институтами гражданского общества широко обсуждались главным образом вопросы ужесточения санкций за нарушение установленного порядка организации либо проведения массовых общественно-политических мероприятий. При этом значительная часть дискуссий касалась введения нового вида административных наказаний в виде обязательных работ.

Рядом общественных деятелей и специалистов в области юриспруденции высказывались критические суждения по поводу принятого закона. Помимо значительной части громких заявлений, носящих чисто эмоциональный характер, высказывались и в целом мотивированные с юридической точки зрения опасения по поводу о правомерности и целесообразности введения обязательных работ в качестве вида административных наказаний. В частности, ставился вопрос о соответствии нового вида административного наказания положениям Конституции РФ и международным обязательствам РФ7.

Так, в появившихся по этому поводу публикация $\mathrm{x}^{8}$ анализировался вопрос о соответствии обязательных работ как вида административного наказания положению, закрепленному в ч. 2 ст. 37 Конституции РФ, которое запрещает принудительный труд. Согласно ст. 4 Трудового кодекса РФ (ТК РФ), принудительный труд - это выполнение работы под угрозой применения какого-либо наказания (насильственного воздействия), в том числе: в целях поддержания трудовой дисциплины; в качестве меры ответственности за участие в забастовке; в качестве средства мобилизации и использования рабочей силы для нужд экономического развития; в качестве меры наказания за наличие или выражение политических взглядов или идеологических убеждений, противоположных установленной политической, социальной или экономической системе; в качестве меры дискриминации по признакам расовой, социальной, национальной или религиозной принадлежности.

К принудительному труду также относится работа, которую работник вынужден выполнять под угрозой применения какого-либо наказания (насильственного воздействия), в то время как в

\footnotetext{
7 См., например, ст. 4 («запрещение рабства и принудительного труда») Европейской конвенции о защите прав человека и основных свобод (Рим, 4 ноября 1950 г.).

${ }^{8}$ См.: Чаннов С. Обязательные работы или принудительный труд // «ЭЖ-ЮРИСТ». - 2012. - № 29.
} 
соответствии с ТК РФ или иными федеральными законами он имеет право отказаться от ее выполнения, в том числе в связи с нарушением установленных сроков выплаты заработной платы или выплатой ее не в полном размере, а также с возникновением непосредственной угрозы для жизни и здоровья работника вследствие нарушения требований охраны труда, в частности необеспечения его средствами коллективной или индивидуальной защиты в соответствии с установленными нормами.

В то же время, согласно ст. 4 ТК РФ, принудительный труд не включает в себя:

- работу, выполнение которой обусловлено законодательством о воинской обязанности и военной службе или заменяющей ее альтернативной гражданской службе;

- работу, выполнение которой обусловлено введением чрезвычайного или военного положения в порядке, установленном федеральными конституционными законами;

- работу, выполняемую в условиях чрезвычайных обстоятельств, то есть в случае бедствия или угрозы бедствия (пожары, наводнения, голод, землетрясения, эпидемии или эпизоотии) и в иных случаях, ставящих под угрозу жизнь или нормальные жизненные условия всего населения или его части;

- работу, выполняемую вследствие вступившего в законную силу приговора суда под надзором государственных органов, ответственных за соблюдение законодательства при исполнении судебных приговоров ${ }^{9}$.

На основании того, что обязательные работы как вид административного наказания формально не подпадают ни под одно из приведенных исключений (в том числе работу, выполняемую вследствие вступившего в законную силу приговора суда, так как о привлечении к административной ответственности выносится постановление), отдельными экспертами делается вывод о нелегитимности данного вида наказания и несоответствии его положениям Конституции РФ.

Однако на наш взгляд, в данном случае нет оснований говорить о существенном расхождении правовых норм Федерального закона от 8

\footnotetext{
9 Понимание сущности принудительного труда, закрепленное в ТК РФ, основано на положениях Конвенции Международной Организации Труда № 29 о принудительном или обязательном труде (Женева, 28 июня 1930 г.) и Конвенции Международной Организации Труда № 105 об упразднении принудительного труда (Женева, 25 июня 1957 г.).
}

июня 2012 г. № 65-Ф3 с нормами, закрепленными в Конституции РФ и международно-правовых документах. Учитывая, что вопрос о конституционности того или иного положения в большинстве случаев решается на основе его сопоставления не только с буквой, но и с «духом» конституционной нормы, становится очевидным, что обязательные работы как вид административного наказания не должны подпадать под понятие «принудительный труд» как работы, выполняемые вследствие вступившего в законную силу решения суда под надзором государственных органов, ответственных за соблюдение законодательства при исполнении судебных приговоров. В связи с принятием Федерального закона от 8 июня 2012 г. № 65-Ф3 перечень работ, не составляющих принудительного труда, закрепленный в ст. 4 ТК РФ, должен быть дополнен работами, выполняемыми лицом вследствие не только приговора, но и иного постановления компетентного суда.

В статьях КоАП РФ, санкции которых предусматривают обязательные работы, данный вид административного наказания устанавливается в качестве альтернативного по отношению к административному штрафу. Решение вопроса о назначении лицу того или иного административного наказания зависит от судейского усмотрения, которое в свою очередь основано на учете всех обстоятельств, имеющих значение для правильного разрешения дела. Далеко не последнюю роль при разрешении дела очевидно должны играть такие факторы, как личность виновного и его имущественное положение ${ }^{10}$. При этом очевидно главное - обязательные работы как мера административного наказания призваны не отягчить наказание лиц, привлекаемых к административной ответственности, а, напротив, сделать наказание более разумным и отвечающим сути противоправного деяния. Именно поэтому по целому ряду составов административных правонарушений обязательные работы заменили в качестве санкций административный арест, который является гораздо более жестким видом административного наказания. Учитывая положительный исторический и мировой опыт применения обязательных работ, можно с уверенностью рассчитывать на то, что данная мера административного наказания при ее оптимальном использовании будет способствовать достижению значительного эффекта при достижении

\footnotetext{
10 См.: ч. 2 ст. 4.1 КоАП РФ.
} 
целей привлечения к административной ответственности - предупреждения совершения но- вых правонарушений как самим правонарушителем, так и другими лицами.

\section{Библиографический список:}

1. Административная ответственность: курс лекций / Б.В. Россинский. 2-е изд., перераб. и доп. - М.: Норма, 2009.

2. Административная ответственность: учебное пособие / Л.А. Калинина; Отв. ред. Л.Л. Попов. - М.: Норма, 2009.

3. Кирин А.В. Административно-деликтное право: (теория и законодательные основы). - М., 2012.

4. Нагорнов Д.С. Административное наказание как составная часть института административной ответственности // Бизнес в законе. - 2009. - № 1.

5. Серков П.П. Административная ответственность в российском праве: современное осмысление и новые подходы. - М.: Норма: ИНФРА-М, 2012.

6. Чаннов С. Обязательные работы или принудительный труд // «ЭЖ-ЮРИСТ». 2012. № 29.

\section{References (transliteration):}

1. Administrativnaya otvetstvennost': kurs lektsiy / B.V. Rossinskiy. 2-e izd., pererab. i dop. M.: Norma, 2009.

2. Administrativnaya otvetstvennost': uchebnoe posobie / L.A. Kalinina; Otv. red. L.L. Popov. M.: Norma, 2009.

3. Kirin A. V. Administrativno-deliktnoe pravo: (teoriya i zakonodatel'nye osnovy): monografiya / A.V. Kirin. M.: Norma: INFRA-M, 2012.

4. Nagornov D.S. Administrativnoe nakazanie kak sostavnaya chast' instituta administrativnoy otvetstvennosti // Biznes v zakone. 2009. № 1.

5. Serkov P.P. Administrativnaya otvetstvennost' v rossiyskom prave: sovremennoe osmyslenie i novye podkhody: monografiya / P.P. Serkov. M.: Norma: INFRA-M, 2012.

6. Channov S. Obyazatel'nye raboty ili prinuditel'nyy trud // «ezh-YuRIST». 2012. № 29. 